\author{
Y. M. Zanimonskiy ${ }^{1}$, A. V. Koloskov ${ }^{1,2, *}$, Yu. M. Yampolski ${ }^{1}$, \\ G. Nykiel $^{3}$, A. O. Sopin ${ }^{1}$, Y. Y. Zanimonskiy ${ }^{4}$ \\ ${ }^{1}$ Institute of Radio Astronomy of the National Academy of Sciences of Ukraine, \\ 4 Mystetstv Str., Kharkiv, 61002, Ukraine \\ ${ }^{2}$ State Institution National Antarctic Scientific Center, Ministry of Education and Science of Ukraine, \\ 16 Taras Shevchenko Blvd., Kyiv, 01601, Ukraine \\ ${ }^{3}$ Gdansk University of Technology, \\ 11/12 G. Narutowicza Str., Gdansk, Poland \\ ${ }^{4}$ Yael Acceptic, 3 Irina Bugrimova square, Kharkiv, 61010, Ukraine \\ * Corresponding author: alexander.koloskov@gmail.com
}

\title{
Relationship of variations of the total electron content of ionosphere in magnetically conjugated regions with precipitation of high-energy charged particles
}

\begin{abstract}
Purpose. A qualitative and quantitative study of the correlation of space-time changes of the total electron content of the ionosphere with variations in the energetic electron flux during a significant increase of the solar wind density and velocity. Determination of the conditions when the increase of the intensity of the flux of energetic electrons can be accompanied by the appearance of large-scale inhomogeneities of the ionosphere observed in magnetically conjugated regions of the Northern and Southern hemispheres. Methods. The research methodology is based on the construction of the time sequence of electron fluxes spatial distributions and their subsequent comparison with the maps of the total electron content (TEC) over North America and the TEC diurnal variations in magnetically conjugated regions. The degree of similarity has been estimated in this paper, and the corresponding correlation coefficients have been obtained. The TEC was calculated from the ground-based Global Navigation Satellite System (GNSS) observations, and the electron fluxes in the ionosphere were obtained from the in situ measurements by the POES satellites. The map-making region was selected by the presence of a dense network of GNSS receivers and the presence of stations in the magnetically conjugated region of the Antarctica, as well as by the favorable configuration of spatial distribution of energetic particles at the orbital height of POES satellites. The study is based on the two geomagnetic disturbances of the St. Patrick's Days in March 2013 and 2015. Results. The satellite and ground-based data during geomagnetic disturbances were processed by using the developed technique. It is found that the consistency of changes in the total electron content of the ionosphere and electron fluxes in time and space coincide with the variation range increase of the horizontal component of the geomagnetic field that has been observed according to the data of ground-based magnetometers and indicates the existence of ionospheric currents in the geospace. According to the analysis of the two events, the assumption is made that the presence of ionospheric currents formed by protons and electrons precipitated from the magnetosphere is one of the conditions for the consistency of changes in the total electron content and electron flux. Conclusions. It is shown that during the geomagnetic disturbances the space-time changes of the ionospheric inhomogeneities are partially consistent with the variations of the fluxes of energetic electrons that allows the possibility of using these observations of TEC as indicators of precipitation.
\end{abstract}

Keywords: ionosphere, Global Navigation Satellite System (GNSS), POES, spatial distribution, correlation, geomagnetic disturbances.

Cite: Zanimonskiy Y. M., Koloskov A. V., Yampolski Yu. M., Nykiel G., Sopin A. O., Zanimonskiy Y. Y. Relationship of variations of the total electron content of ionosphere in magnetically conjugated regions with precipitation of high-energy charged particles. Ukrainian Antarctic Journal, 2019. № 2 (19), 70-83. 


\section{INTRODUCTION}

The paper presents the results of studying the spatiotemporal distribution of inhomogeneities of the nearEarth plasma originated through the factors, which affect the ionosphere "from above". To them in particular belongs an ionization of atmospheric gas by the energetic electrons coming from the magnetosphere. The parameters of electron fluxes were determined by the data of POES satellites (Rodger et al., 2010), and the ionospheric response was evaluated through the maps of the total electron content (TEC) and by comparison of time dependences of TEC in magnetically conjugated regions.

The ionospheric variations caused by the precipitation of energetic electrons and protons, which essentially increase during geomagnetic disturbances at high latitudes, are of active interest of scientific community (Valladares et al., 2017, Yizengaw et al., 2005, Yizengaw et al., 2006, Figueiredo et al., 2017, Yadav et al., 2016, Zhang et al., 2017, Ciraolo et al., 2007). A considerable quantity of diagnostic methods, in particular studying the total electron content and its mapping is applied to their study. The TEC mapping is a powerful instrument of visualization and studying the ionospheric processes. Global ionospheric maps for the last two decades are actively used in scientific practice (Yao et al., 2018, Hernández-Pajares et al., 2009). In a number of publications, the continental TEC maps are applied as indicators of response of an ionosphere to the powerful tropospheric processes, such as, for example, typhoons (Chou et al., 2016), to the wavelike disturbances caused by tsunami (Tang et al., 2015) or earthquakes (Tsugawa et al., 2011). Maps of TEC variations have allowed to determine the characteristic parameters of the travelling ionospheric disturbances - propagation velocity, spatial scale and period, lifetime (Nykiel et al., 2017, Zanimonskiy et al., 2018), and the height of localization of inhomogeneities (Nykiel et al., 2019a). The assumption is made that the quasiperiodic structures on the maps of TEC variations during the ionospheric disturbances can be caused by the fluxes of electrons, which are moving from the magnetosphere along the geomagnetic field lines (Dudnik, Zani- monskiy, 2018a, Jin et al., 2017, Dudnik, Zanimonskiy, 2018b, Verkhoglyadova et al., 2016). However, only in a small number of papers devoted to studying the time dynamics of spatial distribution of electron content, different techniques of studying are used simultaneously. For example, the results of simultaneously used data of several global measuring systems for studying the processes during the geomagnetic disturbances are given in (Shinbori et al., 2018). In this paper, the data of the Global Navigation Satellite System (GNSS) together with the results of the satellite-based measurements of the Earth's Magnetic Field (EMF) are used, the TEC spatial changes during the geomagnetic storm are described. Some special attention is given to the ionosphere over the North America, the TEC maps for the main ionospheric trough along the geomagnetic latitude are presented for the first time, the latitudinal trough migration during the storm is described.

In our paper, the conditions of an ionosphere during the two geomagnetic disturbances in March 2013 and 2015 on the St. Patrick's Days are studied. In our research, the results of data processing for a big network of GNSS stations of the North America, records of several GNSS stations located in the Antarctic Peninsula, and the results of satellite measurements in situ of the fluxes of energetic electrons, which were made by the POES satellites, were used. The main objects of studying were time-space distributions of the total electron content of the ionosphere and the electron fluxes measured at the height of satellite orbits, and the auxiliary ones - the time series of parameters of the solar wind and the geomagnetic field been used for describing the circumstances under which the ionospheric disturbances were developed.

\section{DATA AND METHODOLOGY}

The TEC maps analyzed in this paper are calculated using the GNSS continuously operating reference stations data. Actually, these stations with different spatial distribution are placed on all continents, and also on the islands at oceans. A considerable data array of measurements, which is every day published in the Internet and contains a huge potential for 
ionospheric investigations, is realized for now not completely.

For their more effective use, the development of models describing the influence of atmosphere on the GNSS signals, on the one hand, and on the other development of techniques of processing and interpretation of the results obtained globally, are necessary. Also, it is important to use different methods of studying the ionosphere in the aggregate, by using together with the TEC maps the satellite data in situ as well, in particular the results of direct measurements of parameters of fluxes of the charged particles. In this work, we have analyzed the maps of TEC spatial distribution and intensity of electron fluxes, recorded by the POES satellites. Information about the solar wind gust, which can be considered as a source of geomagnetic disturbances, has been obtained by the Advanced Composition Explorer (ACE) space mission data [www.srl.caltech.edu/ACE/ASC/level2/ lvl2DATA_SWEPAM.html] at the Lagrange point L1 of the Sun-Earth system, at distance of about one and a half million kilometers from the Earth, out of the zone of essential influence of EMF.

The POES mission includes several satellites with the solar-synchronous, close to circular orbits of approximately $850 \mathrm{~km}$ height and the rotation period of $\sim 102 \mathrm{~min}$. On the POES satellites, the measurement of the fluxes of energetic electrons (being analyzed in this Paper) and protons are made by the MEPED equipment (Rodger et al., 2010). Satellites allow measuring the intensity and spectral content of the fluxes of protons and electrons at the altitude of orbit on the global scale. For this work, it is important that the particles under some conditions precipitate into the ionosphere where they cause additional ionization that can be detected on the TEC experimental distributions. In this work, an attempt to determine these conditions is made. It will be mentioned that the time-space distribution of additional electrons during the geomagnetic storms can be fixed on maps in the form of the TEC growth in comparison both with the background values in quiet days and with the areas of region with smaller intensity of precipitation.

For the analysis, the common data of six satellites in March, 2013 and five - in March, 2015 have been used. The global logarithmic distribution (here and after) of the intensity of the electron flux with the energy above $30 \mathrm{keV}$, according to the measurements by the mep90e1 instrument (Rodger et al., 2010) on the orbit of satellites for 24 hours on March, 17, 2013, is shown in Fig. 1. This drawing is similar to the ones presented on the site [https://satdat.ngdc.noaa.gov/ sem/poes/data/plots_OLD/maps/png/]. The previous data processing has shown that the electron fluxes in the quiet and disturbed conditions are distributed over the globe similarly. For the disturbed conditions, intensity and filling of the space between the two zones of precipitation of electrons are typical those of an order higher (Dudnik, Zanimonskiy, 2018a). The phenomena in 2015 can be illustrated by the similar Figures.

As it has been marked in the Introduction, continuously operating (permanent) GNSS stations are distributed over the globe but very nonuniformly. To calculate the global TEC maps, the spatial model in the form of expansion by spherical functions of the 15th degree and the 15th order has been used (HernándezPajares et al., 2009). This representation allows to interpolate the TEC values on territories with small number of stations, but at the same time essentially reduces the spatial resolution for the territories with large networks of closely spaced stations, that is characteristic for Japan, the USA and the Central Europe.

The North America network has the maximum area of coverage and area of intersection with the energetic electron fluxes. Moreover, some elements of this network are magnetically conjugated with the stations located in the Antarctic region. On this basis it was selected for investigation. Here we analyze the data of over seven hundred GNSS stations in the United States of America and Canada in the region marked by a rectangle in Fig. 1. The elements of this network which are magnetically conjugated with the Antarctic region stations, and which data were processed in a special way, are marked by asterisks, diamonds indicate geomagnetic observatories used to investigate compression of EMF.

Fig. 2 shows the distribution in the studied region of the intensity of electrons flux with the energy over $30 \mathrm{keV}$ according to the POES satellites data in geo-

ISSN 1727-7485. Ukrainian Antarctic Journal. 2019, № 2(19) 


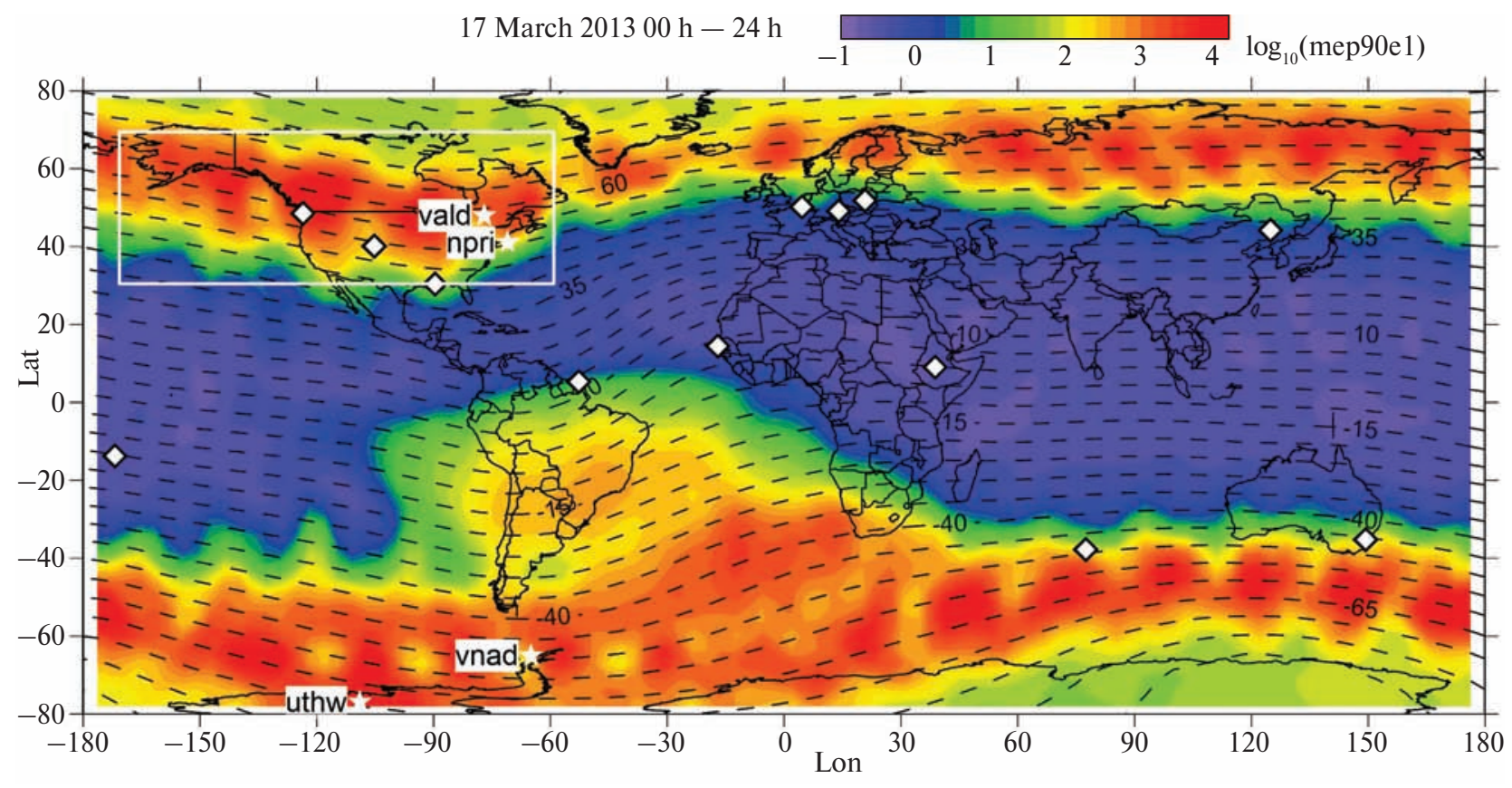

Fig. 1. Global electron flux distribution in energy range of $>30 \mathrm{keV}$ measured by POES satellites during the geomagnetic storm on March 17, 2013. The rectangle shows the study region. The dashed lines show the isolines of geomagnetic latitude, the asterisks indicate magnetically conjugated GNSS stations and diamonds indicate geomagnetic observatories used to investigate compression of EMF
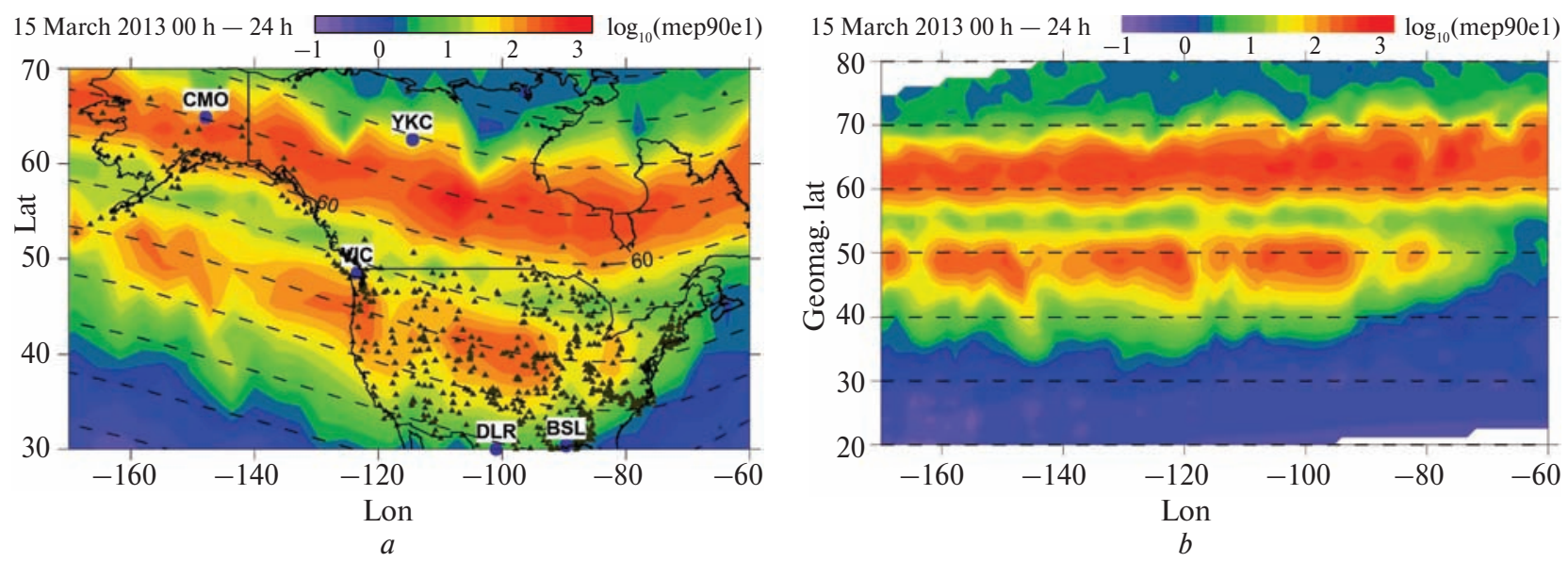

Fig. 2. Electron flux distribution with energy $>30 \mathrm{keV}$ in the study region measured by POES satellites, March 15,2013 as a function of $(a)$ geographic coordinates and $(b)$ geographic longitude and geomagnetic latitude. The dashed lines show the isolines of the geomagnetic latitude; triangles - GNSS stations and black circles - geomagnetic observatories used in this Paper

graphical coordinates (Fig. 2, $a$ ) and in geographical longitude and geomagnetic latitude (Fig. 2, b), for March 15, 2015. The GNSS stations are shown by triangles on the map of Fig. 2 at the left. We have used the data of the geomagnetic observatories also shown on this map. From the literature (Yao et al., 2018), it is known that the electron flux distribution consistent with the geomagnetic coordinates. This fact is illustrated both in Fig. 1 and in Fig. 2. Therefore, the following Figures are given in geomagnetic latitude. 


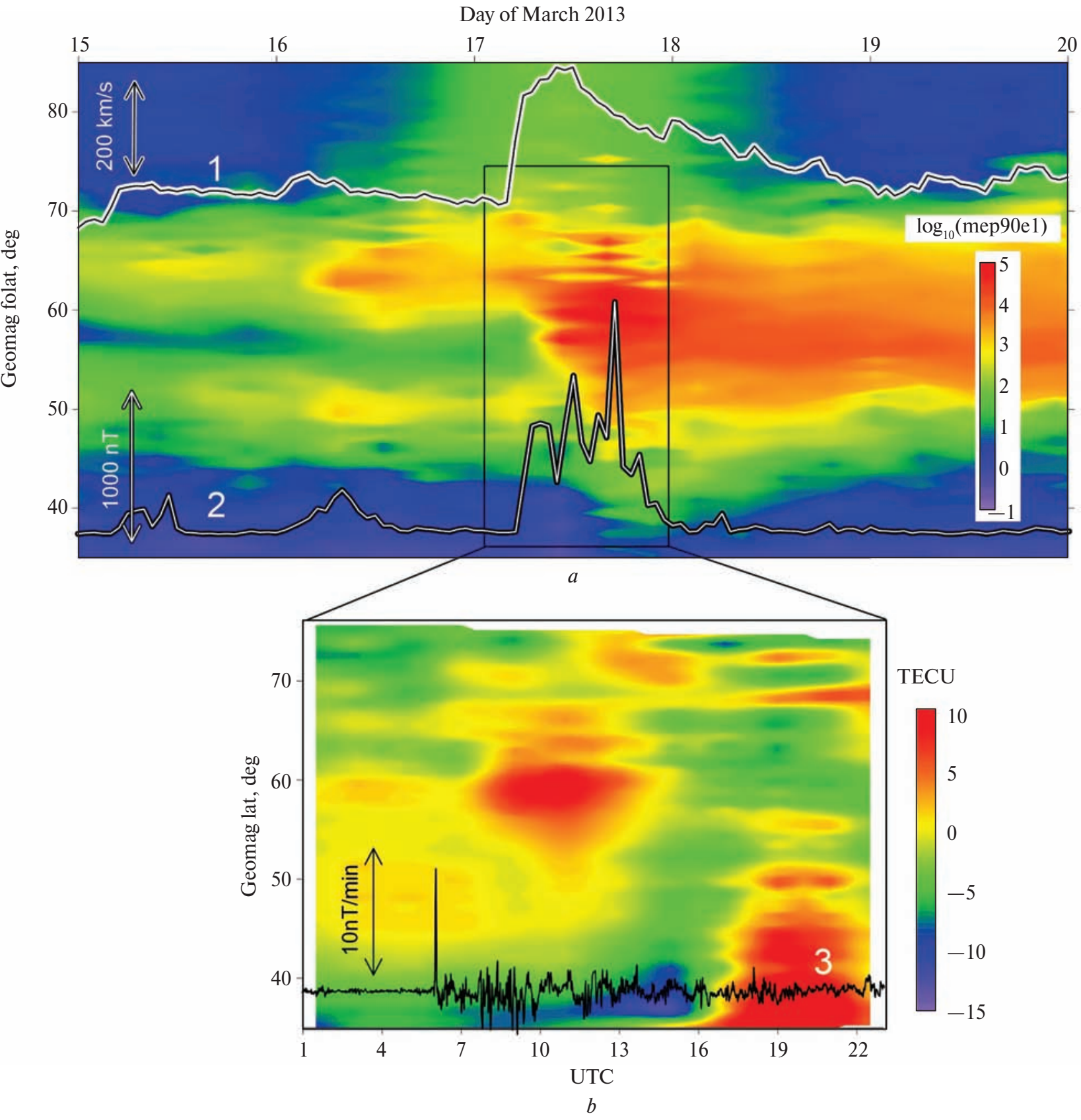

Fig. 3. (a) Keogram of the electron flux vs. geomag folat (geomagnetic latitude of footpoint - the point at which line of magnetic field reach the surface of the Earth) of POES satellite from March 15 to March 20, 2013. (b) Keogram of the deviations of TEC $\left(\mathrm{TEC}_{076}-\mathrm{TEC}_{074}\right)$. Line 1 shows changes of the solar wind speed. Line 2 shows the time variations of the hourly range of the horizontal component of the magnetic field at CMO observatory. Line 3 shows time variations of the rate of change of the intensity of geomagnetic field

The TEC global distribution is shaped similarly (Hernández-Pajares et al., 2009).
The GPS and GLONASS satellites primary data available on the Internet and which are collected in ISSN 1727-7485. Ukrainian Antarctic Journal. 2019, № 2(19) 


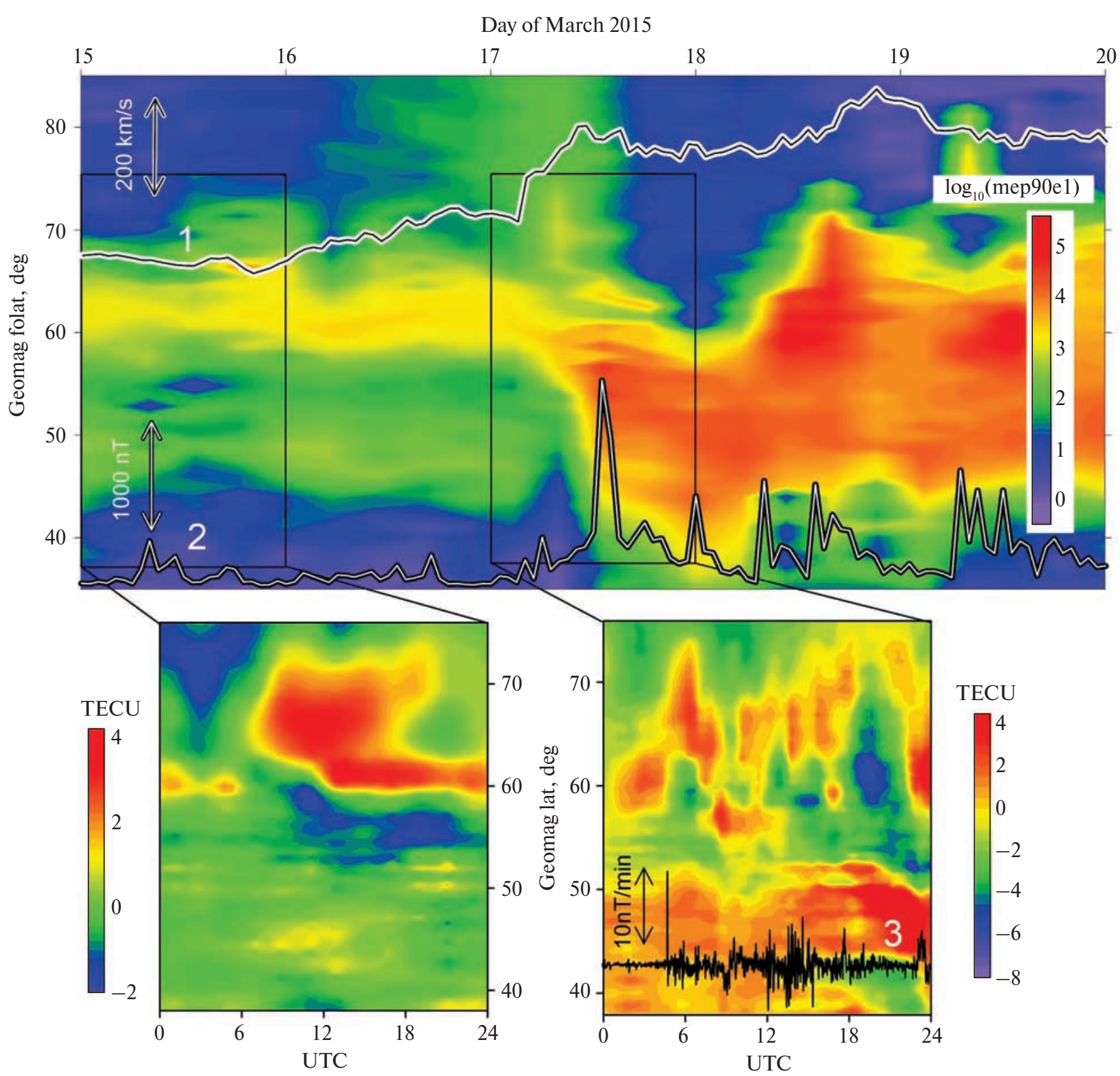

Fig. 4. (top) Keogram of the electron flux vs. geomagnetic latitude of foot point (geomag folat) of POES satellite from March 15 to March 20, 2015. (bottom) Keograms of TEC variations without spatial trend (latitude-dependence) subtracted using $2^{\text {nd }}$ order polynomial function for March 15 (left) and March 17 (right). Line 1 shows changes of the solar wind speed measured at point L1. Line 2 shows the time variations of the hourly range of the horizontal component of the magnetic field at BSL station. Line 3 shows time variations of the rate of change of the intensity of geomagnetic field

the dual-frequency receivers of the stations in the USA, Canada and Antarctic region, were processed by using the original program developed at the Abdus Salam International Centre for Theoretical Physics (Italy) (Ciraolo et al., 2007). As a whole, the data of more than seven hundred GNSS stations have been applied. As a result, the information on the total electron content of the ionosphere over the studied regions for the time intervals of March 13 till March 22, 2013 and 2015 has been added to the database. 
Using this database, the time series, as well as the map sequences, and the keograms - two-dimensional images depending on the time and spatial coordinate, have been made.

\section{RESULTS}

The results of the studies for the two events are given sequentially in a similar way. Fig. 3 illustrates the results, which concern those of March, 2013. The upper part of the Figure shows the keogram (a two-dimensional pattern in the "day time - geomagnetic latitude" coordinates) of the logarithm of electron flux intensity recorded by the mep90e1 instrument versus geomagnetic latitude and time within five consecutive days. This instrument has been chosen because firstly, the electron flux intensity for it is maximum, and secondly, the electrons are detected by this sensor over the North America within a wide range of latitudes from $30^{\circ}$ to $80^{\circ}$ North.

Line 1 in Fig. 3 shows the time variations of solar wind speed in point L1 of the Sun-Earth system from March 15 till March 20. Line 2 shows for each hour the range of variation of horizontal component of EMF (Danskin, Lotz, 2015) in the CMO highlatitude magnetic observatory. The data are taken from the site INTERMAGNET - the global network of observatories for monitoring the geomagnetic field (http://www.intermagnet.org/activitymap/ activitymap-val-eng.php? year $=2013 \&$ month $=03 \&$ day $=17 \&$ component $=h$ ).

On the electron flux keogram, the variations of its spatial pattern at the initial and main phase of the storm on March 15 to 20 are clearly seen. At the beginning of an active phase, at the end of March, 16, an essential electron flux increase in the North had occurred, which lasted till March 18. At the end of March 17, the electron flux was extended towards South (the electron flux increase was also observed at lower latitudes as well). At the maximum of geomagnetic field variations (Line 2), the "merging" of two maxima (in quiet geomagnetic conditions located approximately at $65^{\circ}$ and $50^{\circ}$ ) into one has occurred in spatial distribution of electron fluxes, and its intensity was essentially increased.

\section{6}

It should be noted that the electron content, unlike the electron flux intensity, has a significant regular diurnal variation. To single out the studied variations related to irregular events, the two techniques can be used. First, calculate the map of difference of TEC spatial distributions within the disturbed and quiet days. This technique has been used when analysing the events of geomagnetic storm on March 17, 2013. For the referential TEC maps, those for March 15 have been used. Secondly, it is possible to eliminate the regular component of TEC spatial distribution by modelling its polynomial on latitude and, if necessary, on longitude. The second technique is more appropriate for using if during the studied geomagnetic event its activity changes gradually and the choice of quiet days is not obvious. The second technique has been used when analysing the events of March 17, 2015.

To single out the studied large-scale ionospheric inhomogeneities, the technique of subtraction of the TEC spatial trend represented by the latitudinal the 2-nd order polynomial function was used. After the trend removal we have the quasi 1D TEC spatial distribution, which depends only on geomagnetic latitude that allows constructing the keogram of inhomogeneities.

At the bottom of Fig. 3, the keogram of TEC deviations is shown (values for March 17 minus values for March $15\left(\mathrm{TEC}_{076}-\mathrm{TEC}_{074}\right)$ ) - the dependence on time of day and geomagnetic latitude of the total electron content of an ionosphere over the North America. This keogram has common features with the electron flux keogram that suggests the presence of common origin of these space-time features. However, the electron flux spatial distribution cannot be investigated in detail because the POES satellites orbit covers nonuniformly the analyzed space. Moreover, the time distribution of these satellites also is very non-uniform. Therefore, the electron flux keogram is constructed by means of interpolation that significantly reduces the space-time resolution capability. On the other hand, the TEC maps over the North America, which have been obtained in this study, have the spatial resolution of about one hundred kilometers and that for time $-30 \mathrm{sec}$. Hence, ISSN 1727-7485. Ukrainian Antarctic Journal. 2019, № 2(19) 

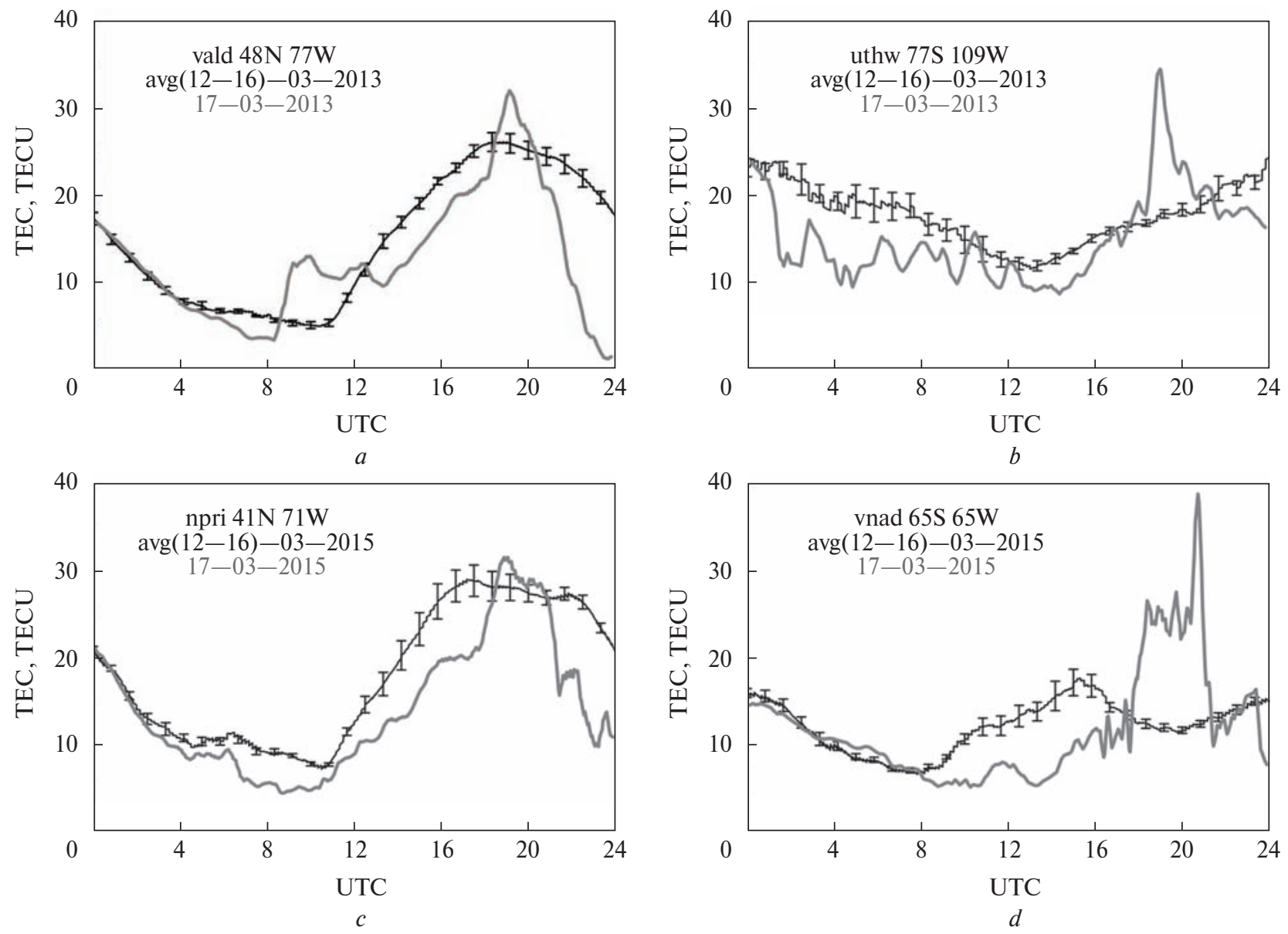

Fig. 5. Diurnal variations of TEC over the Antarctic Peninsula (GNSS stations uthw $(b)$ and vnad $(d)$ ) and North America (stations vald (a) and npri (c)) on March 2013 (top) and 2015 (bottom). Gray lines correspond to disturbed days and black lines averaged TEC for 12-16 March

we may hope for implementation of the possibility of a more detailed study of the processes during geomagnetic disturbance.

It was observed that the geomagnetic storms of the Saint Patrick's Days in 2013 and 2015 had some distinctive features because of the difference in the dynamics of increase of solar wind density and speed being the reason for the near-Earth space disturbances. Further, the results of the analysis of the event of March 17, 2015 are given.

The upper part of Fig. 4 shows the keogram of the logarithmic intensity of the electron flux depending on geomagnetic latitude and time within five consecutive days in March, 2015. Below in Fig. 4, the
TEC keograms for March 15 and 17 in 2015 are shown. Line 1 in Fig. 4 shows the time variation of the solar wind speed. Line 2 shows for each hour, the range of variation of horizontal component of EMF in the BSL middle-latitude magnetic observatory, which illustrates development of the storm.

The electron flux keogram shows well the spatial structure changes of this flux at the initial and main phase of the storm from March, 15 till March, 20. The solar wind speed grew gradually with a one-moment sharp increase on the morning of March 17, unlike of the events in March, 2013. Thus, the electron flux extended towards southern direction, the merging of two maxima in the electron flux spatial 

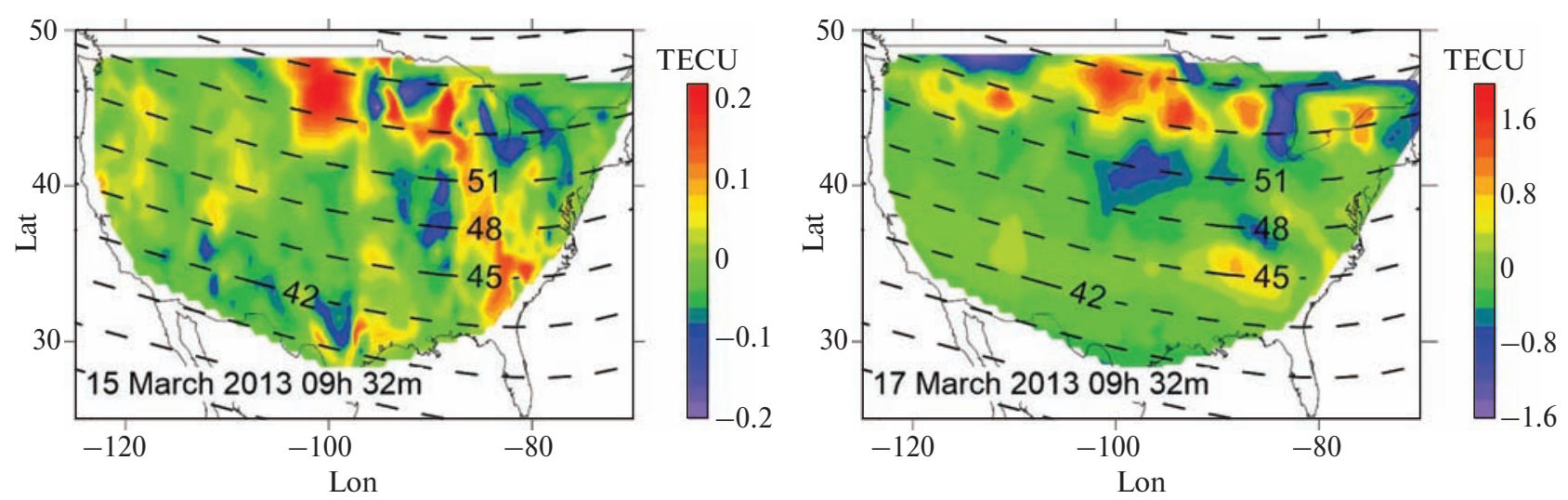

Fig. 6. Maps of TEC variations over the US in quiet (left) and disturbed conditions (right) in March 2013. Variations during the initiation of St Patrick's Day storm are about five times more intense than in relatively quiet conditions and are concentrated in the northern part of the map

distribution occurred, and the intensity essentially increased, as well as the magnetic field variations essentially grew. The next maximum of magnetic field variations corresponds to the increase in electron flux intensity and to the spatial flux maximum southern displacement, which is characteristic for the periods of geomagnetic perturbations (see, e.g., (Shinbori et al., 2018)).

The materials accumulated in this study made it possible to begin testing the working hypothesis, which consists in the fact that during geomagnetic disturbances the influence on the ionosphere from above manifests itself in the same or in similar way in magnetically conjugated regions, while other sources of disturbances generate ionospheric heterogeneities in the Northern and Southern hemispheres of the Earth independently. Moreover, the scatter of the parameters of the ionosphere generated by impact from above is assumed to be approximately the same, while this scatter in the quiet condition can be of different levels, in particular due to the greater meteorological activity in the region of the Antarctic Peninsula (Yampolski et al., 2004).

Consider the behavior of TEC during geomagnetic disturbances in the magnetically conjugated region of Antarctica. The small number of permanent stations in the Antarctica does not allow calculating the TEC maps with acceptable resolution for this region, so let us limit the comparison of the daily TEC calculated for magnetically conjugated GNSS stations lo- cated in both hemispheres. The corresponding results are presented in Fig. 5. The top panel is based on data obtained in 2013 and the bottom panel - in 2015. The left column of both panels shows results for GNSS stations in North America and the right column shows results for Antarctic stations. The daily TEC dependencies on disturbed days are shown in gray lines. The black lines show the average daily TEC values for five quiet days preceding the storm, and vertical bars show the standard error of measurement.

The figures show that despite the fact that the average daily TEC time series in the magnetically conjugated regions are significantly different, on March 17, similar synchronous changes in TEC variations were recorded during the geomagnetic disturbance. Such type of effects was mentioned in the literature, for example (Yue et al., 2016; Foster, Rideout, 2007). For both disturbed days, significant increases in TEC occurred approximately from 18 to 22 UTC, which were absent on quiet days. The synchronous behavior of these peaks suggested that they could be related to the precipitation of charged particles, which should coincide in time for the same L-shells. Unfortunately, it was not possible to recover the intensity of electron fluxes according to POES mission and quantitatively confirm this hypothesis, since the satellites did not fly over these GNSS stations between 18 and 22 UTC. This fact highlights a significant lack of data from satellites, spatio-temporal distribution of which is very uneven.

ISSN 1727-7485. Ukrainian Antarctic Journal. 2019, № 2(19) 
TEC maps described above have a spatial resolution of about 150 kilometers above Canada, about 70 kilometers above the US and can be updated every 30 seconds. The Internet availability of data from more than thousand continuously operated GNSS stations in the US makes it possible to construct maps of TEC variations using the method developed by the authors (Nykiel et al., 2017; Nykiel et al., 2019b). High resolution TEC maps are proposed to be used as a marker of charged particles precipitation into the ionosphere.

Two examples of these maps, for quiet and disturbed conditions at March 2013 are shown in Fig. 6, and at March 2015 - in Fig. 7.

In quiet conditions, the TEC variations form various spatial patterns depending on the presence of tropospheric or thermospheric disturbance sources. On average, over several tens of minutes, variations of TEC have a uniform spatial picture. However, the dependence of the level of TEC variations on the latitude during the storm is revealed. The conditional boundary, to the north of which the TEC dispersion increases substantially, extends about $48^{\circ}$ north latitude (Figs. 6 and 7). This boundary moves to the south from the beginning of the storm to its active phase for several hours. Details on the construction and application of maps of TEC variations are presented in publications (Nykiel et al., 2019b, Zanimonskiy et al., 2019).

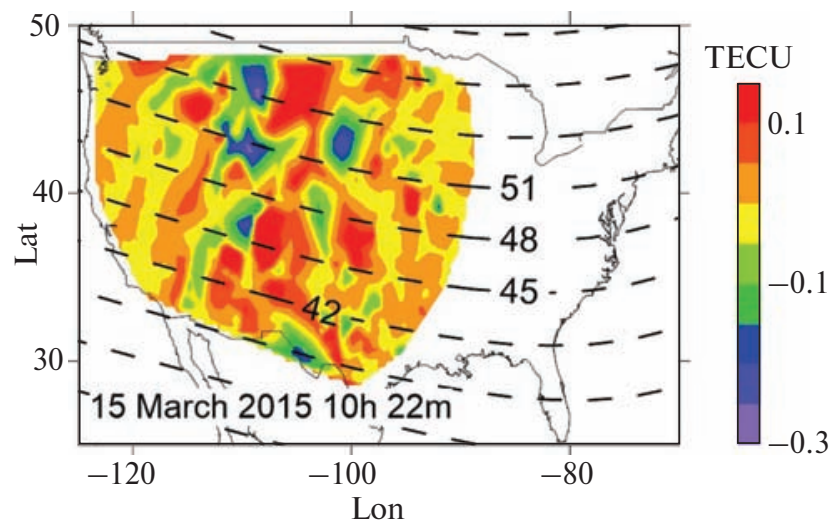

\section{DISCUSSION OF THE RESULTS}

The sequence of events during the geomagnetic storm of St. Patrick's Day in 2013 can be described as follows. On March 15, 16 and 17, the Advanced Composition Explorer spacecraft registered several increases in the velocity of the solar wind protons, the maximum of which occurred on March 17 (Line 1 in Fig. 3). The slight intensification of the solar wind on March 15 and 16 led to an increase in the electron flux recorded on the POES satellites (top panel in Fig. 3), but did not disturb the spatial structure which is characteristic for quiet geomagnetic conditions.

At around 05:27 UTC on March 17, the wind speed at L1 point began to increase significantly. At about 6 UTC, that is, after 30-40 minutes, a rapid increase in the range of variations of the horizontal component of the geomagnetic field at high latitudes began. This is illustrated by Line 2 in Fig. 3. The increase in the level of these variations is a consequence of the increase in the magnitude of the ionospheric electric currents (Danskin, Lotz, 2015; Levitin et al., 1982).

Line 3 in Fig. 3 is the graph of the rate of change of the modulus of intensity of the geomagnetic field. It is averaged according to the data of 10 geomagnetic observatories located in the middle and low latitudes (Fig. 1). Thus, charged particles of the solar wind, moving at a speed of just over $600 \mathrm{~km} / \mathrm{s}$, reached the Earth's magnetosphere after 06 UTC. Starting from

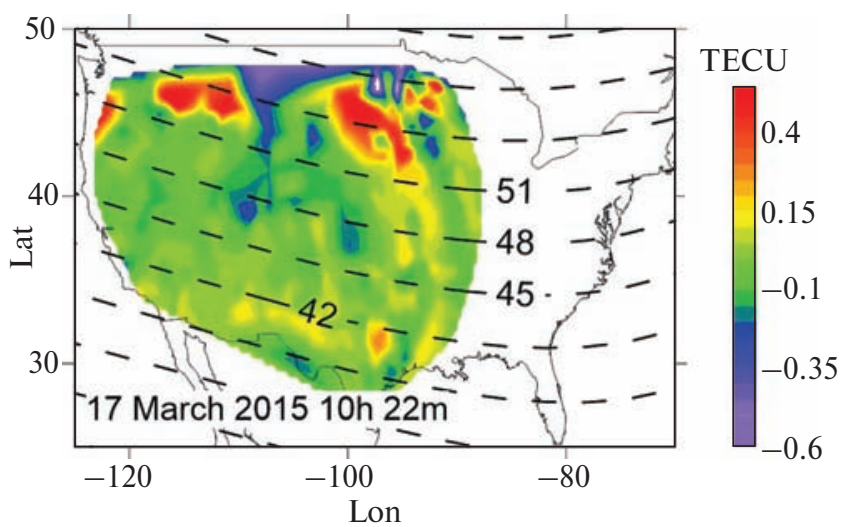

Fig. 7. Maps of TEC variations over the US in quiet (left) and disturbed conditions (right) in March 2015. Variations during the initiation of St Patrick's Day storm are about three times more intense than in relatively quiet conditions and are concentrated in the northern part of the map 
this moment (as shown in the top panel in Fig. 3), the intensity of electron fluxes increased significantly. These effects were observed until the end of the day on March 17.

On March 18, during the recovery phase of storm, variations of horizontal component of the geomagnetic field gradually decreased to the background level. At the same time, the number of electrons recorded by POES satellites remained greater than the background level, with one spatial maximum in the distribution. The distribution of electron flux across geomagnetic latitude, characteristic of quiet conditions (Dudnik, Zanimonskiy, 2018b), resumed in April almost simultaneously with the returning of solar wind parameters to values typical of the quiet Solar activity.

Let us return to the analysis of the spatio-temporal distributions of electron flux and TEC. At approximately 06:30 UTC on March 17, POES satellites recorded an increase in the electron flux at 65 degrees geomagnetic latitude (Fig. 3 upper panel). Then, the increase in flux spread both in the northern and southern directions. After 07 UTC, the increase of total electron content over North America began (along 60 degree of latitude, Fig. 3 lower panel).

The value of TEC gradually increased at 10 UTC, compared to quiet conditions. Thus, correlation of the spatial distribution of TEC with the distribution of electron flux increased. At the beginning of the day, until about 05 UTC, there was very small correlation. By 08 UTC the correlation coefficient was 0.5 and reached its maximum $\sim 0.74$ at about 11 UTC. Further, the correlation decreased and the geomagnetic perturbation went into the stage of negative storm (Verkhoglyadova et al., 2016), and the studied parameters become anticorrelated. Note that a slight increase in the solar wind speed on March 15 did not affect the daily cycle of TEC variations. The next small increase on March 16 may be associated with TEC variations, approximately two times smaller than observed on March 17.

The events of the geomagnetic storm of St. Patrick's Day in 2015 can be described as follows. On March 17, at 04:04 UTC, the spacecraft at the Lagrange $\mathrm{L} 1$ point registered an increase in the velocity of the solar wind protons (Line 1 in Fig. 4). At 04:48
UTC, solar wind particles reached the Earth's magnetosphere, which led to an increase in the variation of the geomagnetic field. Line 3 in Fig. 4 represents the time series of the rate of change of the intensity modulus of the geomagnetic field, averaged from 10 observatories in the middle and low latitudes (Fig. 1). 44 minutes is the time when the solar wind propagates over a distance of 1.5 million kilometers at a speed of just over $550 \mathrm{~km} / \mathrm{s}$. Then, with a delay of several hours, a significant increase in the range of variations of the horizontal component of the geomagnetic field at mid-latitudes (Line 2 in Fig. 4) was recorded. As noted above, the increase in the level of these variations is a consequence of the increase ionospheric currents. As the keogram in the top panel of the Fig. 4 shows intense electron fluxes existed for the next two days.

At approximately 08:30 UTC, POES satellites recorded an increase in electron flux by 60 degree of latitude (Fig. 4 upper panel). Further increase in the flux spread in the south direction. The distribution of TEC over North America on March 17, 2015 (the bottom right diagram in Fig. 4) was characterized by significant variability and practically no correlation with electron flux distribution.

In the TEC distribution, a small minimum at about 55 degrees of geomagnetic latitude was observed during 15 March, which is typical for quiet geomagnetic conditions (keogram for March 15, bottom left in Fig. 4). Also, in contrast to 2013, a correlation of TEC distributions and electron flux was observed up to 0.5 under quiet conditions on March 15, 2015. The electron flux distribution of quiet conditions recovered in early April.

The results of our study can be summarized as follows. The observed spatio-temporal distribution of total electron content is consistent with the distribution of energetic electrons fluxes under the following conditions:

- there are ionospheric currents, associated with the flux of electrons;

- fluxes of electrons are of sufficiently high intensity;

- geomagnetic perturbations do not exceed a certain level.

ISSN 1727-7485. Ukrainian Antarctic Journal. 2019, № 2(19) 
The explanation of these conditions is quite obvious. Currents along magnetic field lines are associated with fluxes of charged particles precipitating from the magnetosphere during geomagnetic storms, which increase the electron concentration in the ionosphere. In quiet conditions after a storm, the amount of energetic particles in the magnetosphere decreases and the effect of additional ionization drops to a negligible level. During a strong geomagnetic storm, other factors change the total electron content, such as the emission of lower energy particles that are not detected by POES satellites in situ.

The differences in the details of two events analyzed in the work are caused by different dynamics of the parameters of solar wind before its main maximum. They took place on the background of similarity in general characteristic of powerful geomagnetic storms.

\section{CONCLUSIONS}

As a result of the research the following conclusions are made.

1. During the geomagnetic storms of St. Patrick's Days in 2013 and 2015 large-scale ionospheric inhomogeneities of total electron content elongated along geomagnetic latitudes appeared.

2. Ionospheric inhomogeneities change their spatial structure during a geomagnetic storm. These changes are partially consistent with changes in the structure of energetic electron fluxes measured by POES satellites.

3. Comparison of the data of two satellite systems, GNSS and POES, confirmed the hypothesis of the increase of the total electron content of the ionosphere simultaneously with the precipitation of charged particles and the increase of ionospheric currents.

4. TEC data from dense networks of GNSS stations, in particular located in magnetically conjugated regions, used as a marker of the precipitation of charged particles may provide additional information to satellite in situ measurements.

Acknowledgments. The authors are grateful to the participants of scientific seminars of Department 22 of the Institute of Radio Astronomy of the National
Academy of Sciences of Ukraine, for the active discussions and useful suggestions.

The work has been done within the framework of Research Projects "Jatagan-3" (No. 0116U000035), "Zond-5" (No. 0119U100354), as well as with the partial financial support under projects "Geliomaks19" (No. 0119U103575) and "Spitsbergen-2019" (No. 0119U101802). This work is partially supported by the EOARD-STCU Partner Project P735. Part of this research was financed by the Faculty of Civil and Environmental Engineering of Gdansk University of Technology statutory research funds.

\section{REFERENCES}

Ciraolo, L., Azpilicueta, F., Brunini, C., Meza, A., Radicella, S.M. 2007. Calibration errors on experimental slant total electron content (TEC) determined with GPS, J. Geod., 81, 2, 111-120.

Chou, M.Y., Lin, C.H., Yue, J., Chang, L.C., Tsai, H.F., Chen, C.H. 2016. Medium-scale traveling ionospheric disturbances triggered by Super Typhoon Nepartak. Geophys. Res. Lett., 44, 15, 7569-7577. https://doi.org/10.1002/2017GL073961.

Danskin, D.W., Lotz, S.I. 2015. Analysis of geomagnetic hourly ranges. Space Weather, 13, 458-468. https://doi.org/ 10.1002/2015SW001184.

Dudnik, O.V., Zanimonskiy, Y.M. 2018a. Peculiar properties in the behavior of energetic charged particles and in Total Electron Content variations during geomagnetic storm on March 17, 2013. 24th National Solar Physics Meeting, Kezmarok, Slovakia, 21-25 May, 2018.

Dudnik, O., Zanimonskiy, E. 2018b. Search of the causal relationship between TEC variations and high energy electrons streams on the example of geomagnetic storm on March 17, 2013. In Fedorov, O. (ed) Space research in Ukraine. 2016-2018. K.: Akademperiodyka, 26-32.

Figueiredo, C.A.O.B., Wrasse, C.M., Takahashi, H., Otsuka,Y., Shiokawa, K., Barros, D. 2017. Large-scale traveling ionospheric disturbances observed by GPS DTEC maps over North and South America on Saint Patrick's Day storm in 2015. J. Geophys. Res. Space Physics., 122, 4, 4755-4763. https://doi.org/10.1002/2016JA023417.

Foster, J.C., Rideout, W. 2007. Storm enhanced density: Magnetic conjugacy effects, Ann. Geophys., 25, 1791-1799, https://doi.org/10.5194/angeo-25-1791-2007.

Hernández-Pajares, M., Juan, J.M., Sanz, J., Orus, R., Garcia-Rigo, A., Feltens, J., Komjathy, A., Schaer, S. C., Krankowski, A. 2009. The IGS VTEC maps: a reliable source of ionospheric information since 1998. Journal of Geodesy, 83, 3-4, 263-275. https://doi.org/10.1007/s00190-008-0266-1.

Jin, S., Jin, R., Kutoglu, H. 2017. Positive and negative ionospheric responses to the March 2015 geomagnetic storm 
from BDS observations. J. Geod., 91: 613-626. https://doi.org/ 10.1007/s00190-016-0988-4

Levitin, A., Afonina, R., Belov, B., Ya.I. Feldstein I. 1982. Geomagnetic Variation and Field-Aligned Currents at Northern High-Latitudes, and their Relations to the Solar Wind Parameters. Philosophical Transactions of the Royal Society of London. Series A, Mathematical and Physical Sciences, 304, 1484, 253-301.

Nykiel, G., Zanimonskiy, Y.M., Yampolski, Yu.M., Figurski, M. 2017. Efficient Usage of Dense GNSS Networks in Central Europe for the Visualization and Investigation of Ionospheric TEC Variations. Sensors, 17, 10, 2298. https://doi.org/ 10.3390/s17102298.

Nykiel, G., Zanimonskiy, Y., Koloskov, A., Figurski, M. 2019a. The possibility of estimating the height of the ionospheric inhomogeneities based on TEC variations maps obtained from dense GPS network, Advances in Space Research, https://doi.org/10.1016/j.asr.2019.06.008.

Nykiel, G., Zanimonskiy, Y., Figurski, M. 2019b. Visualization and characterization of the regional and continental TEC inhomogeneities based on the dense networks of GNSS receivers. Beacon Satellite Symposium. Olsztyn, Poland, 1923 August, 2019.

Rodger, C., Clilverd, M., Green, J., Lam, M. 2010. Use of POES SEM-2 observations to examine radiation belt dynamics and energetic electron precipitation into the atmosphere. J. Geophys. Res., 115, A04202. https://doi.org/10.1029/2008JA014023.

Shinbori, A., Otsuka, Y., Tsugawa, T., Nishioka, M., Kumamoto, A., Tsuchiya, F., Matsuda, S., Kasahara, Y., Matsuoka, A., Ruohoniemi, J.M., Shepherd, S.G., Nishitani, N. 2018. Temporal and spatial variations of storm time midlatitude ionospheric trough based on global GNSS-TEC and Arase satellite observations. Geophysical Research Letters, 45, 7362-7370. htts://doi.org/10.1029/2018GL078723.

Tang, L., Zhang, X., Li, Z. 2015. Observation of ionospheric disturbances induced by the 2011 Tohoku tsunami using far-field GPS data in Hawaii. Earth, Planets and Space, 67:88. https://doi.org/10.1186/s40623-015-0240-0.

Tsugawa, T., Saito, A., Otsuka, Y., Nishioka, M., Maruyama, T., Kato, H., Nagatsuma, T., Murata, K.T. 2011. Ionospheric disturbances detected by GPS total electron content observation after the 2011 off the Pacific coast of Tohoku Earthquake. Earth Planets and Space, 63, 875-879. https:// doi.org/10.5047/eps.2011.06.035.

Valladares, C.E., Eccles, J.V., Basu1, Su., Schunk, R.W., Sheehan, R., Pradipta, R., Ruohoniemi, J.M. 2017. The magnetic storms of August 3-4, 2010 and August 5-6, 2011: 1. Ground and space-based observations. J. Geophys. Res. Space Physics, 122, 3, 3487-3499. https://doi.org/10.1002/ 2016JA023359.

Verkhoglyadova, O.P., Tsurutani, B.T., Mannucci, A.J., Mlynczak, M.G., Hunt, L.A., Paxton, L.J., Komjathy, A.
2016. Solar wind driving of ionosphere-thermosphere responses in three storms near St. Patrick's Day in 2012, 2013, and 2015. J. Geophys. Res. Space Physics, 121, 8900-8923. https:// doi.org/10.1002/2016JA022883.

Yadav, S., Sunda, S., Sridharan, R. 2016. The impact of the 17 March 2015 St. Patrick's Day storm on the evolutionary pattern of equatorial ionization anomaly over the Indian longitudes using high-resolution spatiotemporal TEC maps: New insights. Space Weather, 14, 10, 786-801. https://doi.org/ 10.1002/2016SW001408.

Yampolski Yu.M., Zalizovsky A.V., Lytvynenko L.M., Lizunov G.V., Groves K., Moldwin M. 2004. Magnetic Field Variations in Antarctica and the Conjugate Region (New England) Stimulated by Cyclone Activity. Radio Physics and Radio Astronomy, 9, N 2, 130-151, 2004 (in Russian).

Yao, Y., Liu, L., Kong, J., Zhai, C. 2018. Global ionospheric modeling based on multi-GNSS, satellite altimetry, and Formosat-3/COSMIC data. GPS Solutions, 22:104 https:// doi.org/10.1007/s10291-018-0770-6.

Yizengaw, E., Dyson, P.L., Essex, E.A., Moldwin, M.B. 2005. Ionosphere dynamics over the Southern Hemisphere during the 31 March 2001 severe magnetic storm using multi-instrument measurement data. Annales Geophysicae, 23, 3, 707-721.

Yizengaw, E., Moldwin, M.B., Dyson, P.L., Fraser, B.J., Morley, S. 2006. First tomographic image of ionospheric outflows. Geophysical Research Letters, 33, 20, L20102, https:// doi.org/10.1029/2006GL027698.

Yue, X., Wan, W., Liu, L., Liu, J., Zhang, S., Schreiner, W.S., Zhao, B., Hu, L. 2016. Mapping the conjugate and corotating storm-enhanced density during 17 March 2013 storm through data assimilation, J. Geophys. Res. Space Physics, 121, 12,202-12,210. https://doi.org/10.1002/2016JA023038.

Zanimonskiy, Y., Yampolski, Yu., Nykiel, G., Figurski, M. 2018. Using total electron content variations maps created from data of global navigation satellite system for diagnostics of plasma inhomogeneities. In Fedorov, O. (ed) Space research in Ukraine. 2016-2018. K.: Akademperiodyka, 22-25.

Zanimonskiy, Y.M., Paznukhov, O.V., Nykiel, G., Figurski, M. 2019. Classification and identification of sources of the periodic structures on the continental maps of total electron content. Astronomy and Space Physics in Kyiv University. Kyiv, Ukraine, 28-31 May, 2019

Zhang, S.-R., Erickson, P.J., Zhang, Y., Wang, W., Huang, C., Coster, A.J., Holt, J.M., Foster, J.F., Sulzer, M., Kerr, R. 2017. Observations of ion-neutral coupling associated with strong electrodynamic disturbances during the 2015 St. Patrick's Day storm. J. Geophys. Res. Space Physics, 122, 13141337. https://doi.org/10.1002/2016JA023307.

Received 21 November 2019 Accepted 3 December 2019 
Є. М. Занімонський ${ }^{1}$ О. В. Колосков ${ }^{1,2, ~ *, ~ Ю . ~ М . ~ Я м п о л ь с ь к и и ̆ ~}{ }^{1}$,

Г. Никель ${ }^{3}$, А. О. Сопін ${ }^{1}$, Є. Є. Занімонський ${ }^{4}$

${ }^{1}$ Радіоастрономічний інститут Національної академії наук України, вул. Мистецтв, 4, м. Харків, 61002, Україна

2 Державна установа Національний антарктичний науковий центр МОН України, бульвар Тараса Шевченка, 16, м. Київ, 01601, Україна

${ }^{3}$ Гданський політехнічний університет, вул. Г. Нарутовича, 11/12, м. Гданськ, Польща

${ }^{4}$ Йаель Акцептік, пл. Ірини Бугрімової, 3, м. Харків, 61010, Україна

* Автор для кореспонденції: alexander.koloskov@gmail.com

Зв'язок варіацій повного електронного вмісту іоносфери в магнітосполучених регіонах з висипанням високоенергійних заряджених частинок

Реферат. Мета. Якісне та кількісне дослідження кореляції просторово-часових змін повного електронного вмісту з варіаціями потоку енергійних електронів під час істотного збільшення щільності і швидкості сонячного вітру. Визначення умов, за яких збільшення інтенсивності потоку енергійних електронів може супроводжуватися виникненням великомасштабних неоднорідностей іоносфери, що спостерігаються у магнітосполучених регіонах північної та південної півкуль. Методи. Методика досліджень грунтується на побудові часової послідовності просторових розподілів потоку електронів та їх подальшому порівнянні з картами повного електронного вмісту (ПЕВ) над Північною Америкою та добовим ходом ПЕВ у магнітосполучених регіонах. В роботі виконано оцінки ступеня подібності та отримані відповідні кореляційні коефіцієнти. Повний електронний вміст розраховано за даними наземних спостережень сигналів глобальної навігаційної супутникової системи (ГНСС), а дані про потік електронів в іоносфері отримані з вимірів "in situ” супутниками місії POES. Регіон досліджень вибрано за умовами наявності густої мережі приймачів ГНСС та присутності перманентних станцій у магнітосполученому регіоні в Антарктиці, а також сприятливої конфігурації просторового розподілу потоків енергійних частинок на висоті орбіти супутників POES. Дослідження виконано на прикладі двох геомагнітних збурень дня Св. Патрика в березні 2013 і 2015 років. Результати. За допомогою розробленої методики опрацьовано супутникові та наземні дані під час геомагнітних збурень. Виявлено, що узгодженість змін повного електронного вмісту іоносфери та потоків електронів у часі і просторі співпадає із збільшенням розмаху варіацій горизонтальної компоненти геомагнітного поля, яка спостерігається за даними наземних магнітометрів і вказує на існування струмів вздовж ліній геомагнітного поля в геокосмосі. За даними аналізу проявів двох геомагнітних бур сформульовано припущення, що наявність цих струмів, які формуються потоками високоенергійних заряджених частинок при висипанні з магнітосфери, є однією з причин варіацій повного електронного вмісту. Висновки. Показано, що під час геомагнітних збурень просторово-часові зміни неоднорідностей іоносфери частково узгоджені з варіаціями потоків енергійних електронів, що допускає можливість використання даних спостережень ПЕВ у ролі індикаторів висипань.

Ключові слова: іоносфера, Глобальна навігаційна супутникова система (ГНСС), POES, просторовий розподіл, кореляція, геомагнітні збурення. 